Article

\title{
Geoheritage Resource of Small Mud Lakes in the Semi-Arid Environments of the Russian South
}

\author{
Yuri A. Fedorov ${ }^{1}$ and Dmitry A. Ruban ${ }^{2, *(D)}$ \\ 1 Department of Physical Geography, Ecology and Nature Protection, Institute of Earth Sciences, \\ Southern Federal University, Zorge Street 40, Rostov-on-Don 344090, Russia; fed29@mail.ru \\ 2 Department of Business in Hospitality Sphere, Higher School of Business, Southern Federal University, \\ 23-ja linija Street 43, Rostov-on-Don 344019, Russia \\ * Correspondence: ruban-d@mail.ru
}

Received: 22 March 2019; Accepted: 15 April 2019; Published: 20 April 2019

check for updates

\begin{abstract}
Lakes constitute a significant freshwater resource and are often regarded as being an important part of a country's natural heritage. However, their geological heritage (geoheritage) value remains significantly understudied. Three small lakes, namely the Salt Lake, the Gruzskoe Lake and the Big Yashalta Lake, located in the central part of the Russian South were studied in this paper. The main focus of this research was to search for relevant unique geological features. This paper established that these lakes are distinguishable from other lakes by the presence of dark-colored mud that is rich in sulfides and methane. As a result of excessive summer evaporation, the lakes desiccate (partly or even fully) and this results in exposure of the mud as well as the formation of salt crystals and crusts. This bottom mud (peloid, therapeutic mud) forms as a result of highly-complex biogeochemical processes in semi-arid environments. This mud is interpreted as being part of the lake's geoheritage as it belongs to sedimentary, geochemical and other types. Moreover, this geoheritage has a high ranking nationally. The most representative example can be found at the Big Yashalta Lake and for that reason, this lake is proposed as a geosite. Established sites of geoheritage importance are vital to geoscience research and geotourism activities and thus, these sites are considered to be a resource. Together with the development of local ecotourism and the use of peloids for the health industry purposes, the exploitation of this geoheritage resource would contribute to the sustainable development of the local area.
\end{abstract}

Keywords: geosite; Kalmykia; natural heritage; peloid resource; Rostov Region; sustainable development; tourism

\section{Introduction}

The socioeconomic significance of water objects is indisputable and this has been valued with a diverse set of approaches, including ecosystem services [1,2]. Lakes constitute a substantial resource of freshwater [3,4], the importance of which increases in arid and semi-arid environments with insufficient precipitation. Lakes are also important as recreation and ecotourist destinations [5,6]. However, it is also possible to consider the relevance of lakes as a natural resource through other contexts. First of all, lakes are relevant to the rising international interest in geological and geomorphological heritage (geoheritage) resources, which are important for the development of geoscience, geoeducation and geotourism, with the latter providing significant economic benefits.

The idea of geoheritage comprising unique and thus, valuable geological features for subsequent conservation has been developed over decades although it was most fully conceptualized by Reynard and Brilha [7]. However, geoheritage is also a precious natural resource that can be exploited for different purposes [8], with tourism needs (geotourism) taking a central place [9]. Traditionally, 
geoheritage has been found in rock outcrops, quarries and areas of active volcanism. In essence, it has commonly been thought to be associated with 'purely' geological features, representing the solid Earth crust. For this reason, water objects have been regarded as a separate category of natural heritage. However, the boundary between these categories is by no means overtly distinct. For instance, lake-dominated landscapes can host unique geological features, such as in the Drawskie Lake District of Poland [10]. Moreover, the lakes themselves can be interpreted in the terms of their unique geological phenomena, such as Lake Van in Turkey [11]. Conceptually, lake-related geoheritage includes different features, namely lakes as geological phenomena (e.g., water chemistry), geological activity of lakes, lake inheritance of geological and geomorphological features (e.g., karst lakes), geological features cropping out on lake shores and human activity in regard to geological scale activity of artificial lakes.

The previous works of Fedorov and Ruban [12] and Sallam et al. [13] have shown that the vast territory of the Russian South, which is dominated by semi-arid environments, hosts lakes that can be treated as geoheritage. Moreover, the above-mentioned works have provided evidence (possibly for the first time) that lacustrine bottom muds that are rich in sulfides, methane and organic matter are unique formations that deserve consideration in terms of their heritage. These very preliminary considerations need to be expanded upon and discussed in more depth. The main objective of this paper is to characterize small mud lakes located in the central part of the noted territory as objects of geoheritage. By characterizing these areas as sites of geoheritage importance, this will allow us to understand the potential exploitation of these areas, i.e., to value them as a geoheritage resource. Although small lakes are not infrequent in the study territory, the three chosen lakes are unique with regard to their bottom sediments. For this reason, these lakes have been chosen as representative examples of the mud lakes of the study area.

\section{Study Object and Methodology}

The Russian South is a big geographical region that covers the Don River in the north, the Caucasus Mountains in the south, the Black and Azov seas in the west and the Caspian Sea in the east (Figure 1). The area is drained by several big rivers. The territory is dominated by semi-arid environments with deficient rainfall (400 to $500 \mathrm{~mm} /$ year and less). The typical vegetation is steppe (regional definition of grassland, which is synonymous to prairie), although desert biomes are also known to occur locally. The central part of the Russian South is located along the border of two Russian regions, namely the Republic of Kalmykia and the Rostov Region. The study area is drained by the Manych River (the left tributary of the Don River), along which small, half-desiccated lakes occur. The most prominent lakes of this region are the Salt Lake, the Gruzskoe Lake and the Big Yashalta Lake (Figure 1).

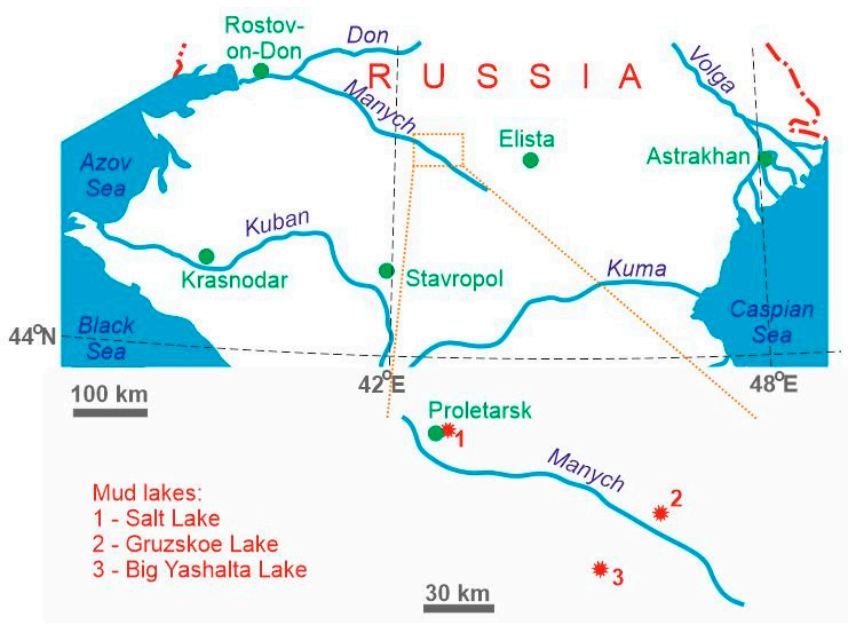

Figure 1. Location of the studied mud lakes. 
The characteristics of the lakes are highlighted below. It should be noted that the lakes chosen for this study are representative of the small lakes of the study territory. However, the chosen lakes are distinguishable from other lakes in the area by geological peculiarities that are analyzed in this paper. This paper does not intend to characterize the geoheritage of all lakes of the study area or to create a complete geoheritage description of the entire region. This paper focuses on the water objects that are known to be representative examples of mud lakes in order to demonstrate the importance of such lakes when undertaking a geoheritage assessment.

The present study is based on the materials of field investigations. Each lake was visited and described (with attention to its physical parameters and landscape context). Bottom sediments were sampled for the subsequent laboratory analysis of two most important geochemical proxies, namely total sulfide content and methane content in wet mass (natural state). The analytical procedure follows the work of Fedorov et al. [14]. The interval of sampling is $5 \mathrm{~cm}$. The depth of sampling is limited to $17.5 \mathrm{~cm}$ in the Salt and Gruzskoe lakes and $27.5 \mathrm{~cm}$ in the Big Yashalta Lake due to its bigger size and thicker bottom sediments. Potentially unique geological phenomena were identified and described in the field.

There are very diverse methods of geoheritage assessment [7,15-19]. These involve multiple criteria, mapping, vulnerability evaluation, etc. Some of these methods are really advanced and are suitable for territorial geoheritage assessment. However, in the case of novel unique features, it is essential to report these features and characterize them qualitatively. The analysis of the lake-related geoheritage occurs in a stepwise manner. First, the uniqueness of the identified geological phenomena is argued via qualitative consideration of how significant and precious the available geological information is. In the other words, the value of potentially unique features to the modern geological knowledge is established. Second, these geological phenomena are attributed to the "standard" types of geoheritage. The classification updated recently by Habibi et al. [20] is employed for this purpose. This classification distinguishes different types, such as sedimentary, stratigraphical, palaeogeographical, etc. (about 20 in total). Third, the rank of the established geoheritage is established via consideration of the spatial rarity of the identified geological phenomena. The rank can be local (area-level), regional (province-level), national (country-level) and global (world-level) [19]. For instance, a feature that is typical for only the region (province or geological domain) but common globally has a regional (provincial) rank. Fourth, the aesthetic properties of the geoheritage are characterized. The criteria for judgments of beauty proposed by Kirillova et al. [21] are used and some principles of the geoaesthetic analysis summarized by Mikhailenko et al. [22], Ruban [23] and Mikhailenko and Ruban [24] are taken into account. These criteria are tied to the physical properties, namely the geological features and landscapes, and tourists' perceptions. Fifth, there is a need to conduct a simple semi-quantitative evaluation of geoheritage sites (geosites). The approach proposed by Warowna et al. [25] is employed for this purpose. This approach is not relative, i.e., its results are sensible, irrespective of the number of geosites on a given area. At this stage, the general characteristics are required and thus, the scientific scores-based evaluation is undertaken with four principal criteria, namely scientific knowledge, rarity, diversity and degree of degradation [25]. Additionally, the physical parameters of lakes and their aesthetic attractiveness are considered as important criteria (Table 1). 
Table 1. Criteria for scientific scores-based evaluation of the mud lakes on the study area (partly modified from [25]).

\begin{tabular}{|c|c|c|}
\hline Main Criteria & Values & Scores \\
\hline \multirow{3}{*}{ Scientific knowledge } & unknown, lack of publications & 0.0 \\
\hline & a few publications & 0.5 \\
\hline & a significant amount of information, publications in major journals & 1.0 \\
\hline \multirow{3}{*}{ Rarity } & not among 3 top sites & 0.0 \\
\hline & one of 3 most important sites & 0.5 \\
\hline & the only occurrence & 1.0 \\
\hline \multirow{3}{*}{ Diversity } & $<3$ abiotic features/processes & 0.0 \\
\hline & 3 visible abiotic features & 0.5 \\
\hline & 4 and more abiotic features & 1.0 \\
\hline \multirow{3}{*}{ Degree of degradation } & highly degraded & 0.0 \\
\hline & slightly degraded & 0.5 \\
\hline & lack of visible degradation & 1.0 \\
\hline \multirow{3}{*}{ Physical parameters } & $<1 \mathrm{~km}$ in diameter & 0.0 \\
\hline & $1-5 \mathrm{~km}$ in diameter & 0.5 \\
\hline & $>5 \mathrm{~km}$ in diameter & 1.0 \\
\hline \multirow{3}{*}{ Aesthetic attractiveness } & lack of attractiveness & 0.0 \\
\hline & attractiveness of unique feature or landscape & 0.5 \\
\hline & attractiveness of the entire site & 1.0 \\
\hline
\end{tabular}

\section{Results}

\subsection{General Lake Descriptions}

The Salt Lake is a small lake (length $3 \mathrm{~km}$, width $1.5 \mathrm{~km}$ ) on the alluvial plain of the Manych River that is dominated by Quaternary deposits and covered by modern soils. It is close to Proletarsk town (Rostov Region) (Figure 1). The landscape is dominated by steppe. Despite the salinity of water and soil, the lake shores are vegetated densely (Figure 2). After sampling the bottom sediments ( $3 \mathrm{~m}$ far from the shoreline), these sediments were determined to be composed of black mud (Figure 2) with a weak smell of hydrogen sulfide. The maximum concentrations of sulfides and methane are established at the depth of 2-10 cm (Figure 3). Below the mud layer, there is a typical lake silt and the transition between the mud and the silt is gradual.

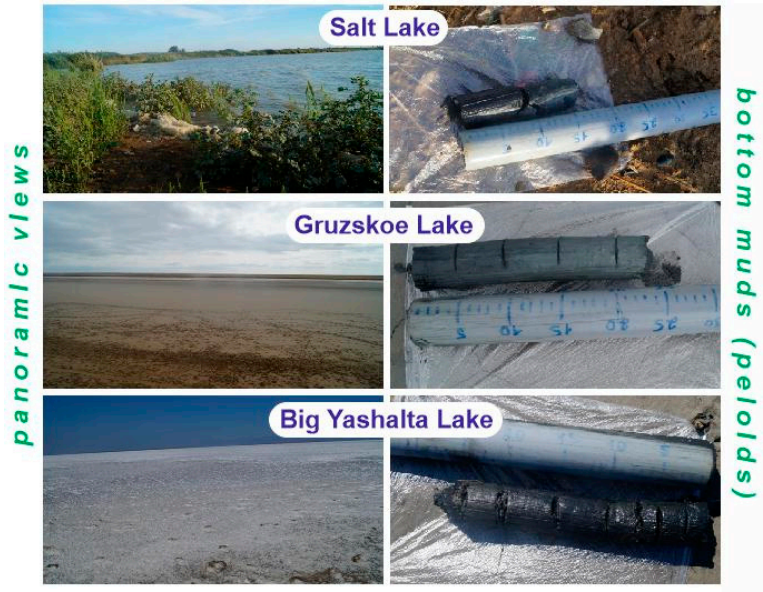

Figure 2. The studied mud lakes of the Russian South. 


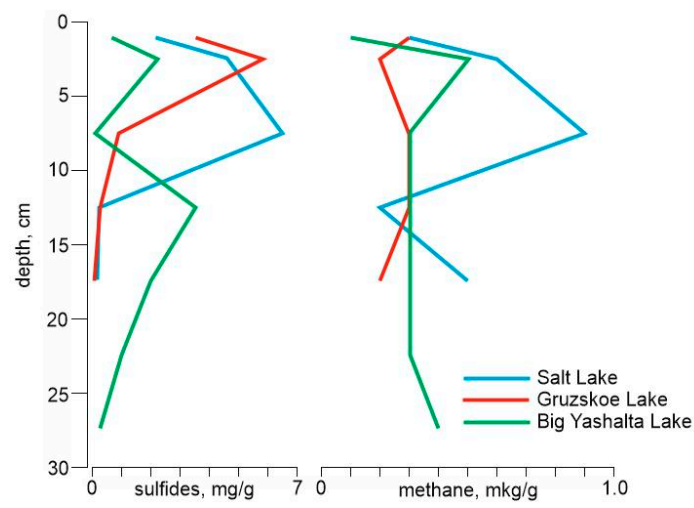

Figure 3. Principal geochemical proxies of the bottom sediments (peloids and underlying silts) of the lakes.

The Gruzskoe Lake is another small lake (length $6 \mathrm{~km}$, width $1.6 \mathrm{~km}$ ) on the same alluvial plain. It is located to the south of Manych village (Rostov Region) (Figure 1). In summer, water evaporates and the lake desiccates (up to full disappearance). In this case, the area looks like a large mud "spot" in the steppe landscape (Figure 2). By sampling bottom sediments (100 $\mathrm{m}$ far from the shoreline), we determined that these sediments are dark-gray mud (Figure 2) with salt crystals and have a smell of organic matter degradation. The only upper layer is rich in sulfides and the methane content is relatively low (Figure 3). The mud is underlain by a typical lake silt.

The Big Yashalta Lake is a bigger lake (length $8 \mathrm{~km}$, width $5 \mathrm{~km}$ ) on the same alluvial plain. It is located to the south of the Manych River, near Berezovskoe village (Republic of Kalmykia) (Figure 1). In summer, the lake desiccates (at least partly) due to excessive evaporation (Figure 2). The exposed mud contains salt crystals and crusts [13]. By sampling bottom sediments (150 $\mathrm{m}$ far from the shoreline), we determined that these sediments are black mud (Figure 2) with half-degraded plant debris and have a smell of hydrogen sulfide. The sulfide and methane content peaks at a depth of $2.5 \mathrm{~cm}$ and the sulfide concentration increases once again at the depth of 10-15 cm (Figure 3). Below the mud layer, there is a typical lake silt (similar to the other cases).

\subsection{Geoheritage Characteristics}

The three studied lakes demonstrate significant similarity and their geoheritage appears to be almost identical. The similarity of these lakes and their bottom sediments proves this statement (Figure 2). In such a case, it is sensible to provide the general characteristics of this geoheritage and to choose one lake as a typical example, i.e., as a geosite.

The mud of the small lakes of the Russian represents a unique geological phenomenon that can be observed on the lake bottom and along the shore during the stage of lake shrinking due to excessive summer evaporation (Figure 2). This mud is composed of clay minerals, organic compounds, plant debris and water. Furthermore, it is also characterized by significant amounts of sulfides and methane (Figure 3). These bottom sediments can be judged as peloids (therapeutic mud) as suggested by their general view, composition and therapeutic properties (this mud is recommended by local experts for use in medical, cosmetic and recreation industries [12]). This term refers to natural, clay-based substances that can be exploited for various health-related practices $[12,26,27]$. The term is too broad and its definition requires justification (see overview in [26]), but it is used widely for describing a particular natural resource. The process of therapeutic mud formation is unique by definition because it represents the coherent action of several highly-specific geological, environmental and biogeochemical agents. In the case of the study area, the peculiarities of peloid composition (e.g., significant content of salt particles and sulfides) and formation are tied to both lake development on the alluvial plain and biogeochemical processes in stagnant water under semi-arid conditions. The occurrence of peloids is usually local and this type of natural resource is not voluminous on the 
world scale, national or even regional scales. The reports of therapeutic mud from the Dead Sea [28], Cuba [29], Mongolia [30], Spain [31] and Turkey [32] have proven these statements. Moreover, there are relatively few geological descriptions of peloids. This evidence implies that the bottom mud of the small lakes of the Russian South is unique and should be treated as a type of geoheritage.

From about two dozen types of geoheritage distinguished by Habibi et al. [20], the peloids from the small mud lakes of the study area can be assigned to hydrological (mud represents geological activity of lake water), sedimentary (mud is essentially bottom sediment), mineralogical (mud includes clay and salt minerals), geochemical (mud formation results from highly complex biogeochemical processes and mud composition demonstrates certain chemical peculiarity), pedological (mud forms a basis for soil on lake shores) and economical (mud is economically valuable resource for health industry) types. From these types, the most important seem to be the sedimentary and geochemical types because these determine the very uniqueness of the studied peloids. Although the lakes are linked to minor landforms of the alluvial plain, there are no signs of unique geomorphological objects in the study area.

The rank of the established heritage is national. Peloids of this type are concentrated in the Russian South [12] where semi-arid environments determine the specific hydrochemical regime of small lakes where mud accumulates. The aesthetic properties of the mud itself are definitely low. The mud view and smell are detracting (Figure 2). However, the criteria of judgments of beauty [21] are very diverse. For instance, tourists make judgments according to the authenticity and novelty of attractions. Lacustrine peloids represent a very authentic substance that is natural and occurs in natural landscape with minimal anthropogenic intervention. This substance is novel to lake visitors due to the scarcity of therapeutic mud in nature. Finally, the lakes themselves are aesthetically attractive (especially when lake level is high) (Figure 2).

Within the study area, geoheritage is represented at three localities, namely the Salt Lake, the Gruzskoe Lake and the Big Yashalta Lake (Figure 1). The most suitable example is the Big Yashalta Lake. Its bottom mud shares basic characteristics with the other lakes of the study area. Furthermore, the Big Yashalta Lake is bigger in size and the mud is better seen on its shore. This lake also boasts of a very active formation of salt crystals and crusts at the time of summer desiccation, which is a phenomenon that may attract the visitors' attention. The scientific scores-based evaluation of this geosite based on the approach adapted from Warowna et al. [25] is provided in Table 2. Scientific knowledge of the Big Yashalta Lake results from the present study and some preliminary information was published in a major international journal by Sallam et al. [13]. This corresponds to the scientific knowledge score of 0.5 . This geosite is one of three most important sites known locally, which gives a rarity score of 0.5 . Visible abiotic features include the lake itself, the seasonal lake desiccation and salt formation and the bottom peloids. This provides a diversity score of 0.5 . This geosite does not provide evidence of visible degradation, which implies a degree of degradation score of 1.0. The size of the lake is significant, which means a score of 1.0 for physical parameters. Finally, the aesthetic attractiveness is restricted to the only landscape, which implies a score of 0.5 . The total sum of these scores is 4.0 (Table 2), whereas the maximum possible sum of scores is 6.0 (Table 1). This means that the scientific value of the Big Yashalta Lake is moderate. A similar evaluation for the other two lakes resulted in lower sums of scores (Table 2), although their values can be judged to be moderate. 
Table 2. The scientific scores-based evaluation of the geoheritage of the three mud lakes of the study area.

\begin{tabular}{lccc}
\hline \multicolumn{1}{c}{ Criteria } & Salt Lake & Gruzskoe Lake & Big Yashalta Lake \\
\hline Scientific knowledge & 0.0 & 0.0 & 0.5 \\
Rarity & 0.5 & 0.5 & 0.5 \\
Diversity & 0.0 & 0.5 & 0.5 \\
Degree of & 1.0 & 1.0 & 1.0 \\
degradation & 0.0 & 0.5 & 1.0 \\
Physical parameters & 0.5 & 0.5 & 0.5 \\
Aesthetic & 2.0 & 3.0 & 4.0 \\
attractiveness & & & \\
Total sum & & &
\end{tabular}

This paper provides the first assessment of the geological uniqueness of the small mud lakes in the semi-arid environments of the Russian South. The description presented above may be subjective due to the lack of comparison to the other studies. However, the simplicity of the present study minimizes the influence of subjective judgments. Anyway, further similar studies in different parts of the world will permit qualitative and quantitative comparisons, which will contribute to a relevant detailed assessment of this specific geoheritage.

\section{Discussion}

Peloids have significant importance to the modern society [12,26,27]. These can be exploited for the purposes of medical, cosmetic and recreation industries and thus, peloids should be regarded as an economic resource. Presently, the peloids of the Russian South are in the stage of detailed property evaluation for making recommendations for their practical use. However, therapeutic mud is produced successfully on the nearby territories, particularly in the southern part of the Russian South where the famous nation-scale spa resorts of Kislovodsk, Pyatigorsk and Essentuki have functioned for more than a century. The spa centers of these resorts can use peloids from the study area.

Rocha and Fereira da Silva [33] demonstrated that peloids have some merit in terms of geotourism and can serve as a resource for this activity. The bottom mud of the small lakes of the Russian South are valued as a geoheritage resource. This statement requires proper argumentation that is provided below.

Principally, geoheritage can be used for the purposes of science, education and tourism [8,24]. Peloids of the Salt, Gruzskoe and Big Yashalta lakes are highly important in the development of various research projects. On the one hand, these bottom sediments reflect peculiar, highly-complex processes in semi-arid environments (see above). On the other hand, there is insufficient knowledge about the peloids of the world, their properties and mechanisms of their formation. Only a few relevant publications appear in major international journals annually. This is why further research in bottom mud on the study area is important.

The use of the studied small mud lakes in education is ambiguous. On the one hand, there are several big universities in the Russian South. The geoscience students from these universities can receive precious information visiting the lakes. On the other hand, these lakes are located far from big cities (Figure 1) and organizing geoeducational excursions to these locations would require a significant amount of time and be expensive.

The geotourism value of the lakes is significant. The peloids of the study area are interesting due to their geological uniqueness. Tourists can observe this feature in various states, i.e., as dried mud with salt in summer and as wet mud in the other seasons. The importance of mud is strengthened in two additional circumstances. First, the study area lies closely to a local ecotourist destination with free living horses $[34,35]$ and camels (Figure 4 ), which contains a very typical dry steppe landscape and its wildlife (Figure 5). There are some other lakes, rivers and streams, which may attract the attention of environment-focused tourists. The importance of such water objects for tourism development is well-known $[36,37]$ and this importance seems to be even higher in semi-arid environments. The number 
of visitors remains limited now but rich resources [38], significant state support [39] and possibilities of integration with the other types of tourism (e.g., ethno-cultural tourism in Kalmykia) [40] will facilitate an increase in tourist demand in the nearest future. Second, the importance of the peloids for health can also attract visitors. Joint geo-, eco- and health tourism activities on the study area will have a synergetic effect. There are three main conditions that should be fulfilled to achieve this ambitious task. First, the available tourism infrastructure [38] needs an update and extension. The Salt Lake has an advantage because it is located near Proletarsk town (Figure 1), although this town itself cannot generate the flow of visitors because of its small size. Second, the knowledge of new tourist attractions requires their active promotion by local and regional tourism-related authorities. The study area is a typical stable geological domain with sub-horizontal layering where outcrops are rare, but a full-scale geoheritage inventory has yet to be undertaken there. In such a case, geoheritage mapping is strongly required.

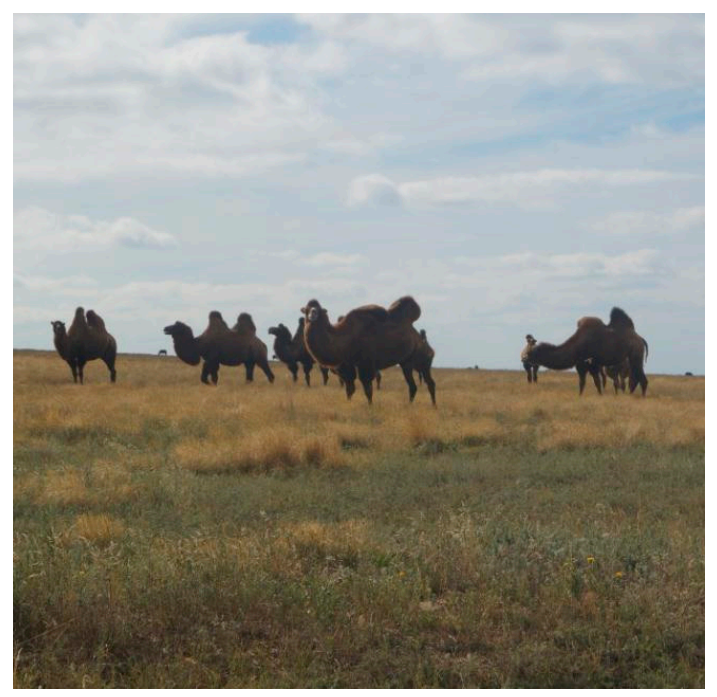

Figure 4. Camels in the local ecotourist destination.

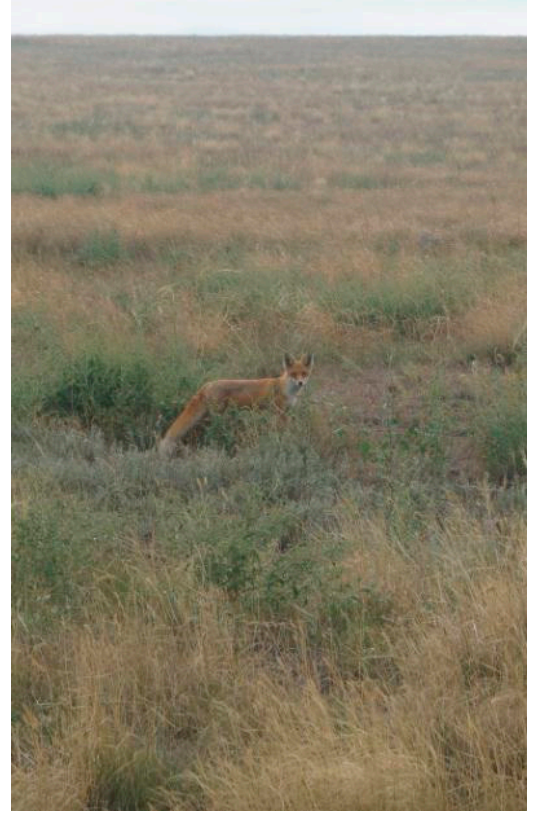

Figure 5. Typical steppe landscape and fox in the study area. 
The considerations presented above imply that the geoheritage of the small mud lakes is important to the study area and thus, it can be judged as a true resource. Moreover, this geoheritage resource coincides with ecotourism and health-industry resources. The study area is remote and still requires socioeconomic development. The exploitation of the noted resources would contribute to the latter. For instance, research activation will facilitate the medical use of peloids, which could consequently form an income stream for the local budgets. An increase in tourism will bring economic income and contribute to infrastructure growth and the creation of new jobs for local communities. In the other words, the multiple uses of peloids can contribute to sustainable development of the discussed part of the Russian South.

The other important issues are the possible degradation of the established geoheritage resource due to excessive peloid extraction for the purposes of health industry and/or negative tourism impact. It should be noted that peloids constitute a renewable resource [12], i.e., their formation continues gradually when serious environmental perturbations are absent. Mud extraction for medical, cosmetic and/or recreation purposes requires only regulations, not limitations. The remote location of the lakes (Figure 1) means that it is unlikely to experience a tourist flow that would be significant enough to provoke environmental stress.

\section{Conclusions}

The study of the small mud lakes in the central part of the Russian South allows us to make three general conclusions. First, the common unique geological feature of these lakes is their bottom sediments, which are represented by peloids. Second, these peloids are of several different geoheritage types, with sedimentary (lithological peculiarities) and geochemical (complex biogeochemical processes of peloid deposition and sulfide and salt formation) types being the most common. Third, the established geoheritage can be understood as a resource. It can be exploited for the purposes of geoscience and geotourism and contribute to local sustainable development.

Further research should be aimed at a more detailed description of lacustrine peloids in the study area. Additionally, it is important to pay attention to other potentially unique geological features in the Russian South. More generally, the outcomes of this study imply that peloids require proper conceptualization in the terms of both geoheritage and tourism-related sustainable development.

Author Contributions: Conceptualization, D.A.R.; field investigations, Y.A.F.; methodology, Y.A.F. and D.A.R.; interpretation, Y.A.F. and D.A.R.; writing, D.A.R.

Funding: This research was supported by the grant of the Russian Science Foundation Project 17-17-01229.

Acknowledgments: The journal editors and the reviewers are thanked for their support and suggestions.

Conflicts of Interest: The authors declare no conflict of interest.

\section{References}

1. Doherty, E.; Murphy, G.; Hynes, S.; Buckley, C. Valuing ecosystem services across water bodies: Results from a discrete choice experiment. Ecosyst. Serv. 2014, 7, 89-97. [CrossRef]

2. Dupont, D.P.; Adamowicz, W.L. Water Valuation. In Water Policy and Governance in Canada; Ienzetti, S., Dupont, D.P., Eds.; Global Issues in Water Policy; Springer: Cham, Switzerland, 2017; Volume 17, pp. 181-199.

3. Ives, J.T.; Lawrence, T. A tale of two Great Lakes conferences: Urging global collaboration on our largest freshwater resources. J. Great Lakes Res. 2018, 44, 1289-1292. [CrossRef]

4. Zilov, E.A. Water resources and the sustainable development of humankind: International cooperation in the rational use of freshwater-lake resources: Conclusions from materials of foreign studies. Water Resour 2013, 40, 84-95. [CrossRef]

5. Dávid, L.; Baros, Z.; Patkós, C.; Tuohino, A. Lake tourism and global climate change: An integrative approach based on Finnish and Hungarian case-studies. Carpath. J. Earth Environ. Sci. 2012, 7, 121-136.

6. Yusof, N.; Jamil, M.F.C.; Said, I.; Ali, A.N.O. Organizational culture and tourist satisfaction in a lake-based tourism area. Am. J. Appl. Sci. 2012, 9, 417-424. 
7. Reynard, E.; Brilha, J. (Eds.) Geoheritage: Assessment, Protection and Management; Elsevier: Amsterdam, The Netherlands, 2018; pp. 1-482.

8. Ruban, D.A. Geodiversity as a precious national resource: A note on the role of geoparks. Resour. Policy 2017, 53, 103-108. [CrossRef]

9. Dowling, R.; Newsome, D. (Eds.) Handbook of Geotourism; Edward Elgar Publishing: Cheltenham, UK, 2018; pp. 1-499.

10. Górska-Zabielska, M.; Kamienska, K. Geotourism Potential of the Drawskie Lake District as a Support for the Planned Geopark named Postglacial Land of the Drawa and Dęnica Rivers. Quaest. Geogr. 2017, 36, 15-31. [CrossRef]

11. Üner, S.; Aliriz, M.G.; Özsayin, E.; Selçuk, A.S.; Karabiyikoglu, M. Earthquake Induced Sedimentary Structures (Seismites): Geoconservation and Promotion as Geological Heritage (Lake Van-Turkey). Geoheritage 2017, 9 , 133-139. [CrossRef]

12. Fedorov, Y.A.; Ruban, D.A. Peloids as important resource for regional sustainable development: Conceptual considerations. Espacios 2018, 39, 21.

13. Sallam, E.S.; Abd El-Aal, A.K.; Fedorov, Y.A.; Bobrysheva, O.R.; Ruban, D.A. Geological heritage as a new kind of natural resource in the Siwa Oasis, Egypt: The first assessment, comparison to the Russian South and sustainable development issues. J. Afr. Earth Sci. 2018, 144, 151-160. [CrossRef]

14. Fedorov, Y.A.; Nikolayevich, G.D.; Trubnik, R.G. Bacteria of the Clostridium genus, methane and hydrogen sulfide in sulfide mud of the Taman Peninsula reservoirs. OnLine J. Biol. Sci. 2018, 18, 315-322. [CrossRef]

15. Carcavilla Urqui, L.; Lopez Martinez, J.; Duran Valsero, J.J. Patrimonio Geologico y Geodiversidad: Investigacion, conservacion, gestion y relacion con los espacios naturales protegidos; Instituto Geologico y Minero de España: Madrid, Spain, 2007; pp. 1-360.

16. Comănescu, L.; Nedelea, A. Public perception of the hazards affecting geomorphological heritage-case study: The central area of Bucegi Mts. (Southern Carpathians, Romania). Environ. Earth Sci. 2015, 73, 8487-8497. [CrossRef]

17. Erhartic, B. Conserving geoheritage in Slovenia through geomorphosite mapping. Geovisions 2010, 35, 47-63.

18. Reynard, E.; Perret, A.; Grangier, L.; Kozlik, L. Methodological approach for the assessment, protection, promotion and management of geoheritage. Geophys. Res. Abstr. 2012, 14, 3740.

19. Ruban, D.A. Quantification of geodiversity and its loss. Proc. Geol. Assoc. 2010, 121, 326-333. [CrossRef]

20. Habibi, T.; Ponedelnik, A.A.; Yashalova, N.N.; Ruban, D.A. Urban geoheritage complexity: Evidence of a unique natural resource from Shiraz city in Iran. Resour. Policy 2018, 59, 85-94. [CrossRef]

21. Kirillova, K.; Fu, X.; Lehto, X.; Cai, L. What makes a destination beautiful? Dimensions of tourist aesthetic judgment. Tour. Manag. 2014, 42, 282-293. [CrossRef]

22. Mikhailenko, A.V.; Nazarenko, O.V.; Ruban, D.A.; Zayats, P.P. Aesthetics-based classification of geological structures in outcrops for geotourism purposes: A tentative proposal. Geologos 2017, 23, 45-52. [CrossRef]

23. Ruban, D.A. Aesthetic properties of geological heritage landscapes: Evidence from the Lagonaki Highland (Western Caucasus, Russia). J. Geogr. Inst. "Jovan Cvijić" SASA 2018, 68, 289-296. [CrossRef]

24. Mikhailenko, A.V.; Ruban, D.A. Geo-Heritage Specific Visibility as an Important Parameter in Geo-Tourism Resource Evaluation. Geosciences 2019, 9, 146. [CrossRef]

25. Warowna, J.; Zgłobicki, W.; Kołodyńska-Gawrysiak, R.; Gajek, G.; Gawrysiak, L.; Telecka, M. Geotourist values of loess geoheritage within the planned Geopark Małopolska Vistula River Gap, E Poland. Quat. Int. 2016, 399, 46-57. [CrossRef]

26. Gomes, C.; Carretero, M.I.; Pozo, M.; Maraver, F.; Canista, P.; Armijo, F.; Legido, J.L.; Teixeira, F.; Rautureau, M.; Delgado, R. Peloids and pelotherapy: Historical evolution, classification and glossary. App. Clay Sci. 2013, 75-76, 28-38. [CrossRef]

27. Munteanu, C.; Dumistrascu, M. Therapeutic muds. Balneo-Res. J. 2011, 2, 12-16. [CrossRef]

28. Kotova, I.; Kayukova, E.; Kotov, S. Peloids of Crimean salt lakes and the Dead Sea: Controls on composition and formation. Environ. Earth Sci. 2016, 75, 1207. [CrossRef]

29. Margaret, S.M.; Nadia, M.-V.; Patricia, G.-H.; Clara, M.R.; Josiel, B.C.; Rebeca, H.; Fagundo, J.R.; Oscar, D.R.; Alina, G.R.; Cristina, D.L.; et al. Physicochemical characterization, elemental speciation and hydrogeochemical modeling of Santa Lucía peloid used for therapeutic uses. Revista Internacional de Contaminacion Ambiental 2018, 34, 105-110. 
30. Tserenkhand, B.; Badnainyambuu, Z.; Erdenechimeg, G.; Bolormaa, O. Composition of water and peloid from lake Buuntsagaan and element acummulation of peloid. J. Chem. Technol. Metall. 2018, 53, 258-266.

31. Carretero, M.I.; Pozo, M.; Legido, J.L.; Fernández-González, M.V.; Delgao, R.; Gómez, I.; Armijo, F.; Maraver, F. Assessment of three Spanish clays for their use in pelotherapy. Appl. Clay Sci. 2014, 99, 131-143. [CrossRef]

32. Karakaya, M.Ç.; Karakaya, N.; Sarığlan, Ş.; Koral, M. Some properties of thermal muds of some spas in Turkey. Appl. Clay Sci. 2010, 48, 531-538. [CrossRef]

33. Rocha, F.; Ferreira da Silva, E. Geotourism, Medical Geology and local development: Cape Verde case study. J. Afr. Earth Sci. 2014, 99, 735-742. [CrossRef]

34. Kazmin, V.D.; Demina, O.N.; Pozdnyakova, M.K.; Rozenfeld, S.B.; Abaturov, B.D. The current state of plant forage resources and feeding selectivity of free-leaving horses (Equus Caballus) on a steppe Island of Lake Manych-Gudilo. Zoologicheskii Zhurnal 2013, 92, 231-237.

35. Kaz'min, V.D.; Pozdnyakova, M.K.; Kolesnikov, M.P.; Abaturov, B.D. Quantitative characterization of the nutrition of the free-living horse (Equus caballus) on Vodnyi Island (Manych-Gudilo Lake). Biol. Bull. 2013, 40, 684-691. [CrossRef]

36. Berezin, A.A. Aquatic realms and running water in sustainable tourism. WIT Trans. Ecol. Environ. 2012, 162, 447-458.

37. Hjerpe, E.E. Outdoor Recreation as a Sustainable Export Industry: A Case Study of the Boundary Waters Wilderness. Ecol. Econ. 2018, 146, 60-68. [CrossRef]

38. Oborin, M.S.; Kozhushkina, I.; Gvarliani, T.; Ivanov, N. Socioeconomic preconditions of resort agglomerations development in the south of Russia. Worldw.Hosp. Tour. Themes 2018, 10, 467-477. [CrossRef]

39. Nikolaeva, J.V.; Bogoliubova, N.M.; Shirin, S.S. Ecological tourism in the state image policy structure. Experience and problems of modern Russia. Curr. Issues Tour. 2018, 21, 547-566. [CrossRef]

40. Boldyreva, S.B.; Kekeeva, Z.O.; Kekeev, O.I. Ethno-Cultural Aspects of Tourism Development in the Republic of Kalmykia. J. Environ. Manag. Tour. 2018, 9, 318-324. [CrossRef]

(C) 2019 by the authors. Licensee MDPI, Basel, Switzerland. This article is an open access article distributed under the terms and conditions of the Creative Commons Attribution (CC BY) license (http://creativecommons.org/licenses/by/4.0/). 